\title{
Survei Daya Tahan Kardiovaskular dan Keterampilan Dasar Futsal Peserta Ekstrakurikuler
}

\author{
Wahyu Aji Santoso ${ }^{1 *}$, Hariyoko ${ }^{2}$ \\ 1,2Jurusan Pendidikan Jasmani, Kesehatan dan Rekreasi, Fakultas IImu Keolahragaan, \\ Universitas Negeri Malang, Jalan Semarang No 5, Malang, Jawa Timur, 65145, Indonesia \\ ${ }^{*}$ Penulis koresponden: wahyuajisantoso170@gmail.com, 081332656650
}

Artikel diterima: 8 Januari 2020; direvisi: 16 Oktober 2020; disetujui: 22 Oktober 2020

\begin{abstract}
The purpose of this study was to determine the level of cardiovascular endurance and basic futsal skills of the MAN 1 extracurricular activities in Kediri. The research design used was survey research with qualitative and quantitative research types. The research subjects were 38 people, the instruments used were multistage fitness test and futsal skills test. The data analysis technique used multistage fitness test norms and futsal skills test norms. From the results of data analysis, 2 conclusions were obtained: (1) the average cardiovascular endurance test (vo2max) was in the moderate category, (2) the basic futsal skills test obtained an average of being in the moderate category.
\end{abstract}

Keyword: cardiovascular endurance, futsal skills, extracurricular participants

\begin{abstract}
Abstrak: Tujuan penelitian ini untuk mengetahui tingkat daya tahan kardiovaskular dan keterampilan dasar futsal peserta ekstrakurikuler MAN 1 Kota Kediri. Rancangan penelitian yang digunakan berupa penelitian survei dengan jenis penelitian kualitatif dan kuantitatif. Subjek penelitian sebanyak 38 orang, instrumen yang digunakan berupa multistage fitness test dan tes keterampilan futsal. Teknik analisis data menggunakan norma multistage fitness test dan norma tes keterampilan futsal. Dari hasil analisis data, diperoleh 2 kesimpulan: (1) tes daya tahan kadiovaskular (vo2max ) rata-rata tergolong dalam kategori sedang, (2) tes keterampilan dasar futsal diperoleh rata-rata tergolong dalam kategori cukup.
\end{abstract}

Kata kunci: daya tahan kardiovaskular, keterampilan futsal, peserta ekstrakurikular

\section{PENDAHULUAN}

Olahraga merupakan hal yang sangat penting bagi manusia dikarenakan, dapat mengakibatkan kondisi tubuh menjadi lebih sehat dan bugar sehingga dapat mempermudah dalam melaksanakan aktivitas setiap hari. Olahraga tidak hanya untuk meningkatkan fisik akan tetapi dapat digunakan sebagai sarana rekreasi, prestasi dan kesehatan jasmani. Olahraga adalah serangkaian gerak raga yang teratur dan terencana untuk memelihara gerak (yang berarti mempertahankan hidup) dan meningkatkan kemampuan gerak (Adi \& Fathoni, 2019, 2020a, 2020b; Fathoni, 2018; Fathoni \& Fajar, 2017, 2017). Olahraga sendiri harus dilakukan oleh manusia, artinya apabila tidak ada faktor peran dari manusia secara pribadi maka tidak bisa dikatakan sebagai aktivitas olahraga. Ada beberapa persyaratan yang harus dipenuhi untuk melakukan aktivitas olaharaga 
diantaranya sehat, ada niat untuk meningkatkan derajat kesehatannya, serta ingin berprestasi dalam salah satu cabang olahraga.

Ada banyak jenis cabang olahraga yang dapat dilakukan untuk mencapai tujuan hidup sehat, antara lain: atletik, olahraga bela diri, olahraga air dan olahraga permainan contohnya futsal. Futsal merupakan cabang olahraga permainan, olahraga ini banyak diminati berbagai kalangan masyarakat baik laki-laki maupun perempuan. Hal ini terbukti dari banyaknya tempat penyewaan lapangan futsal, berdirinya tim futsal di berbagai daerah, serta diadakannya kegiatan ekstrakurikuler futsal di sekolah baik tingkat Sekolah Menengah Pertama (SMP), Sekolah Menengah Atas (SMA) maupun kalangan mahasiswa.

MAN 1 Kota Kediri merupakan salah satu Sekolah Menengah Atas yang ada di Kota Kediri, berbeda dengan sekolah lainnya, dikarenakan di MAN 1 lebih banyak pelajaran agama dibandingkan sekolah yang lain. MAN 1 Kota Kediri tidak masuk dalam golongan sekolah yang berpotensi besar dalam bidang olahraga. Pada masa kini seorang individu harus memiliki rasa perhatian yang lebih dari lingkungan disekitar mereka, karena pada saat ini seorang individu saling berlomba menunjukan jati diri masing-masing. Diselenggarakannya kegiatan ekstrakurikuler futsal diharapkan siswa dapat menyalurkan bakat dan minatnya.

Ekstrakurikuler futsal di MAN 1 Kediri terbilang sudah cukup lama karena setiap tahun selalu mengikuti turnamen antar SMA, akan tetapi ketika mengikuti turnamen antar SMA belum dapat mencapai target juara dikarenakan kondisi fisik yang dimiliki para peserta didik ekstrakurikuler masih dibawah sekolah lainnya yang ada di Kota Kediri. Kegiatan ekstrakulikuler merupakan kegiatan non pokok yang dilakukan di luar kegiatan kurikuler (pokok) sebagai sarana untuk menambah pengetahuan dan memperdalam materi - materi yang telah diajarkan di sekolah oleh guru kepada peserta didik untuk dapat diterapkan dalam kehidupan seharihari (Adiningtyas, Tomi, \& Yudasmara, 2020; Kurniadi, Wahyudi, \& Heynoek, 2019; Litardiansyah \& Hariyanto, 2020; Rohmatunisha, Wahyudi, \& Yudasmara, 2020; Sadewa \& Nurrochmah, 2020). Dikarenakan dalam permainan futsal kebugaran jasmani merupakan komponen yang menunjang dalam bermain futsal. Pola permainan dalam futsal banyak didominasi permainan kaki ke kaki, saat bertahan maupun menyerang lebih banyak dilakukan dengan umpan-umpan pendek, mengingat ukuran lapangannya lebih kecil dengan lapangan sepak bola (Barbero-Alvarez et al., 2015; Instituto Brasileiro de Pesquisa e Ensino em Fisiologia do Exercício et al., 2017; Moore, Bullough, Goldsmith, \& Edmondson, 2014; Naser, Ali, \& Macadam, 2017).

Berdasarkan hasil wawancara yang telah dilakukan peneliti pada hari Jum'at tanggal 25 Januari 2019 mendapatkan hasil bahwa menurut pelatih peserta memiliki kebugaran jasmani yang cukup rendah disebabkan: latihan kurang teratur, makanan dan asupan gizi kurang memenuhi kebutuhan, jadwal pulang sekolah dan kegiatan pondok yang terlalu padat. Tujuan dari penelitian ini adalah untuk mengetahui tingkat daya tahan kardiovaskular dan keterampilan futsal peserta ekstrakurikuler futsal MAN 1 Kota Kediri.

\section{METODE}

Berdasarkan masalah yang telah diteliti di bab I, maka penelitian ini menggunakan rancangan survei berbentuk deskriptif. Ditinjau dari tujuan penelitian maka jenis penelitian ini menggunakan jenis penelitian kualitatif dan kuantitatif. Variabel yang diteliti berupa kebugaran jasmani dan keterampilan teknik dasar peserta didik ekstrakulikuler futsal MAN 1 Kota Kediri. Untuk kelengkapan data yang diinginkan, peneliti menggunakan dua teknik yaitu menggunkan tes dan pengamatan. Instrumen yang digunakan untuk mengumpulkan data dalam penelitian ini adalah tes dan non tes. Untuk mengumpulkan data daya tahan kardiovaskuler, maka digunakan Multistage Fitness Test (MFT) atau Bleep Test untuk memperkirakan ambilan oksigen maksimal.

Analisis data merupakan langkah mengolah data yang harus dilakukan setelah data diperoleh. Data digolongkan menjadi dua yaitu data kuantitatif yang berbentuk angka-angka dan kualitatif yang berbentuk kata-kata. Data dalam penelitian ini menggunakan metode kuantitatif deskriptif.

\section{HASIL}

Berdasarkan hasil penelitian tentang survei daya tahan (Vo2max) dan keterampilan peserta ekstrakurikuler futsal di MAN 1 Kota Kediri, diperoleh hasil tes daya tahan ( $\mathrm{VO}_{2} \mathrm{max}$ ) peserta ekstrakurikuler futsal MAN 1 Kota Kediri diperoleh rata-rata 38,23, simpangan baku 5,14, nilai minimal 27,2 dan nilai maksimal 46,5. 
Sedangkan untuk hasil tes keterampilan futsal peserta ekstrakurikuler di MAN 1 Kota Kediri diperoleh ratarata 76,79, simpangan baku 8,03, nilai minimal 63 dan nilai maksimal 94 .

Hasil tes daya tahan ( $\mathrm{VO}_{2} \mathrm{max}$ ) Peserta Ekstrakurikuler Futsal MAN 1 Kota Kediri dengan rentangan skor dari 27,2 sampai dengan 46,5 diperoleh rata-rata sebesar 38,23 , simpangan baku (SD) 5,14 . Berdasarkan data distribusi frekuensi diperoleh 0 orang peserta $(0 \%)$ kategori terlatih dan baik sekali, 4 orang peserta $(10,53 \%)$ kategori baik, 14 orang peserta $(36,84 \%)$ kategori sedang, 10 orang peserta $(26,32 \%)$ kategori kurang, dan 10 orang peserta $(26,32 \%)$ kategori sangat kurang. Dapat disimpulkan rata-rata tes daya tahan $\left(\mathrm{VO}_{2} \max \right)$ peserta ekstrakurikuler futsal MAN 1 Kota Kediri tergolong dalam kategori sedang.

Hasil tes keterampilan futsal peserta ekstrakurikuler di MAN 1 Kota Kediri dengan rentangan skor dari 63 sampai dengan 94 diperoleh rata-rata sebesar 76,79, simpangan baku (SD) 8,03. Berdasarkan data distribsui frekuensi diperoleh 4 orang peserta $(10,53 \%)$ kategori kurang sekali, 6 orang peserta $(15,79 \%)$ kategori kurang, 18 orang peserta $(47,37 \%)$ kategori cukup, 8 orang peserta $(21,05 \%)$ kategori baik, dan 2 orang peserta $(5,26 \%)$ kategori baik sekali. Dapat disimpulkan rata-rata tes tingkat keterampilan futsal peserta ekstrakurikuler di MAN 1 Kota Kediri tergolong dalam kategori cukup.

\section{PEMBAHASAN}

\section{Kemampuan Daya Tahan ( $\mathrm{VO}_{2}$ max) Peserta Ekstrakurikuler Futsal di MAN 1 Kota Kediri}

Hasil tes $\mathrm{VO}_{2}$ max peserta ekstrakurikuler futsal MAN 1 Kota Kediri yang dilakukan menggunakan multistage fitness test dengan jumlah peserta 38 orang diperoleh hasil 0 orang peserta $(0 \%)$ kategori terlatih dan baik sekali, 4 orang peserta $(10,53 \%)$ kategori baik, 14 orang peserta $(36,84 \%)$ kategori sedang, 10 orang peserta $(26,32 \%)$ kategori kurang, dan 10 orang peserta $(26,32 \%)$ kategori sangat kurang.

Berdasarkan hasil tes daya tahan $\left(\mathrm{VO}_{2} \max \right)$ tersebut dapat disimpulkan bahwa peserta kegiatan ekstrakurikuler futsal di MAN 1 Kota Kediri memilki daya tahan $\left(\mathrm{VO}_{2} m a x\right)$ dengan klasifikasi sedang, hal ini dibuktikan pada hasil tes multistage fitness test yang berjumlah 38 orang terdapat 14 orang $(36,84 \%)$ memilki tingkat daya tahan $\left(\mathrm{VO}_{2}\right.$ max $)$ klasifikasi sedang.

Hasil penelitian yang telah dilakukan oleh Prasojo, Junaidi, Hidayah (2015) diperoleh hasil bahwa, tingkat kondisi fisik pemain futsal SMK Bagimu Negeriku Semarang tahun 2014 yang berjumlah 22 orang dalam kategori cukup, sedangkan hasil penelitian Sudibyo (2013) diperoleh hasil bahwa rata-rata tingkat $\mathrm{VO}_{2} \max$ anggota ekstrakulikuler futsal putri SMA Negeri 3 Mojokerto paling tinggi, kemudian diikuti oleh SMA Negeri 2 Mojokerto, dan yang terakhir adalah anggota ekstrakulikuler futsal putri SMA Islam Brawijaya Mojokerto. Hasil penelitian yang telah dilakukan Ninzar (2018) diperoleh hasil daya tahan aerobik ( $\mathrm{VO}_{2}$ max) atlet futsal SIBA yang berjumlah 31 orang peserta dalam kategori kurang.

Berdasarkan hasil pembahasan tersebut, daya tahan kardiovaskuler masih dalam kategori cukup, sehingga kondisi fisik berupa daya tahan kardiovaskuler $\left(\mathrm{VO}_{2} \mathrm{max}\right)$ perlu ditingkatkan bagi peserta ekstrakurikuler futsal di MAN 1 Kota Kediri untuk mencapai kategori baik. Solusi yang tepat untuk mencapai kriteria tersebut adalah melakukan penambahan latihan fisik secara menyeluruh sesuai dengan kebutuhan saat bertanding.

Memiliki kondisi fisik daya tahan ( $\mathrm{VO}_{2} \mathrm{max}$ ) yang bagus merupakan salah satu aspek yang harus dimiliki oleh pemain futsal, pertandingan yang dimainkan dengan durasi waktu 20 menit kali 2 babak, mengharuskan setiap pemain futsal harus memiliki kondisi daya tahan $\left(\mathrm{VO}_{2}\right.$ max) yang baik.

Berdasarkan hasil penelitian kondisi fisik daya tahan $\left(\mathrm{VO}_{2} \mathrm{max}\right)$ menggunakan multistage fitness test yang dilakukan pada peserta kegiatan ekstrakurikuler futsal di MAN 1 Kota Kediri dengan hasil tes menunjukkan pada klasifikasi sedang, maka sebaiknya pelatih harus menambah program latihan fisik khususnya latihan fisik untuk daya tahan $\left(\mathrm{VO}_{2}\right.$ max), sehingga pada saat menghadapi pertandingan pemain tidak mudah kelelahan dan dapat menyelesaikan pertandingan dengan baik. Pelatih dapat menambah latihan kondisi fisik secara teratur dan sistematis yang dapat dituangkan dalam sebuah program latihan sehingga dapat meningkatkan kamampuan fisik secara nyata terhadap atletnya.

\section{Kemampuan Keterampilan Dasar Futsal Peserta Ekstrakurikuler di MAN 1 Kota Kediri}

Futsal merupakan olahraga permaianan bola besar yang dimainkan dua tim yang berbeda yang masing masing tim terdiri dari 5 pemain dan futsal mempunyai 4 teknik dasar yaitu mengumpan bola, menggiring bla, 
menahan bola, dan menambak bola. Hasil tes keterampilan futsal yang dilaksanakan peserta ekstrakurikuler di MAN 1 Kota Kediri dengan jumlah peserta 38 orang diperoleh hasil 4 orang peserta $(10,53 \%)$ kategori kurang sekali, 6 orang peserta (15,79\%) kategori kurang, 18 orang peserta $(47,37 \%)$ kategori cukup, 8 orang peserta $(21,05 \%)$ kategori baik, dan 2 orang peserta $(5,26 \%)$ kategori baik sekali.

Berdasarkan hasil tes keterampilan futsal dapat disimpulkan bahwa peserta kegiatan ekstrakurikuler futsal di MAN 1 Kota Kediri memiliki keterampilan futsal dalam kategori cukup, hal ini dibuktikan pada hasil tes keterampilan yang berjumlah 38 orang terdapat 18 orang peserta $(47,37 \%)$ memilki kemampuan keterampilan futsal kategori sedang.

Hasil penelitian yang telah dilakukan oleh Aziz (2013) diperoleh hasil bahwa tingkat keterampilan dasar peserta ekstrakurikuler futsal di SMK Muhammadiyah 1 Patuk Gunungkidul dalam kategori cukup, sedangkan hasil penelitian yang telah dilakukan oleh Kuncoro (2016) diperoleh bahwa tingkat keterampilan dasar peserta ekstrakurikuler futsal SMA Negeri 3 Sragen dalam kategori cukup. Hasil penelitian Sulistiantoro (2016) diperoleh hasil tingkat bahwa keterampilan dasar pada tim futsal putra yang berjumlah 24 orang dalam kategori kurang.

Berdasarkan hasil pembahasan tersebut, kemampuan keterampilan bermain futsal masih dalam kategori cukup, dan harus ditingkatkan ke kategori baik. Ada beberapa faktor yang dapat mempengaruhi hasil keterampilan futsal yakni: (1) tingkat keterampilan bermain futsal (dribble, passing, control dan shooting) pada tiap peserta ekstrakurikuler, (2) latihan. Faktor yang penting dalam pencapaian prestasi futsal seseorang adalah penguasaan keterampilan bermain futsal yang dimiliki oleh pemain itu sendiri. Bentuk keterampilan bermain futsal seperti teknik dasar mengumpan (passing), teknik dasar menahan bola (control), teknik dasar lambung (chipping), teknik dasar menggiring bola (dribbling) dan teknik dasar menembak bola (shooting), untuk dapat menguasai keterampilan dasar bermain futsal yang baik dibutuhkan latihan yang rutin dan disiplin. Latihan dapat dilakukan dimana saja di luar sekolah dengan memanfaatkan lapangan-lapangan yang ada. Selain itu, faktor yang dapat mempengaruhi hasil tes keterampilan futsal adalah latihan. Latihan merupakan proses melakukan kegiatan olahraga yang dilakukan berdasarkan program latihan yang disusun secara sistematis, bertujuan untuk meningkatkan kemampuan atlet dalam upaya mencapai prestasi yang semaksimal mungkin, terutama dilaksanakan untuk persiapan menghadapi pertandingan (Cooney, Dwan, \& Mead, 2014; Garber et al., 2011; Maruhashi, Kihara, \& Higashi, 2017; Stanton \& Reaburn, 2014).

Dapat disimpulkan dari hasil tes keterampilan yang telah dilaksanakan, program latihan harus disusun secara teratur dan sistematis dalam permainan futsal sehingga keterampilan futsal peserta ekstrakurikuler MAN 1 Kota Kediri mengalami peningkatan. Pada saat pertandingan peserta ekstrakurikuler dapat mengeluarkan kemampuan terbaiknya dan mencapai prestasi yang terbaik.

\section{KESIMPULAN}

Berdasarkan pengujian hipotesis dan pembahasan dalam penelitian yang dilakukan, maka diperoleh hasil penelitian yang dapat disimpulkan:(1) Hasil tes daya tahan kardiovaskuler (vo2max) peserta ekstrakurikuler futsal MAN 1 Kota Kediri diperoleh 0 orang peserta (0\%) kategori terlatih dan baik sekali, 4 orang peserta $(10,53 \%)$ kategori baik, 14 orang peserta $(36,84 \%)$ kategori sedang, 10 orang peserta $(26,32 \%)$ kategori kurang, dan 10 orang peserta (26,32\%) kategori sangat kurang, (2) Hasil tes keterampilan dasar futsal peserta ekstrakurikuler MAN 1 Kota Kediri diperoleh 4 orang peserta (10,53\%) kategori kurang sekali, 6 orang peserta $(15,79 \%)$ kategori kurang, 18 orang peserta $(47,37 \%)$ kategori cukup, 8 orang peserta $(21,05 \%)$ kategori baik, dan 2 orang peserta $(5,26 \%)$ kategori baik sekali.

Dapat disimpulkan rata-rata tes daya tahan $\left(\mathrm{VO}_{2} \mathrm{max}\right)$ peserta ekstrakurikuler futsal MAN 1 Kota Kediri tergolong dalam kategori kurang, sedangkan untuk rata-rata tes tingkat keterampilan dasar futsal peserta ekstrakurikuler di MAN 1 Kota Kediri tergolong dalam kategori cukup.

\section{DAFTAR PUSTAKA}

Adi, S., \& Fathoni, A. F. (2019). Development of Learning Model Based on Blended Learning in Sports School. https://doi.org/10.2991/acpes-19.2019.2 
Adi, S., \& Fathoni, A. F. (2020a). Blended Learning Analysis for Sports Schools in Indonesia. International Journal of Interactive Mobile Technologies (IJIM), 14(12), 149-164. Retrieved from https://www.onlinejournals.org/index.php/i-jim/index

Adi, S., \& Fathoni, A. F. (2020b). The effectiveness and efficiency of blended learning at sport schools in Indonesia. International Journal of Innovation, Creativity and Change.

Adiningtyas, W. P., Tomi, A., \& Yudasmara, D. S. (2020). Survei Pembinaan Ekstrakurikuler Bolabasket pada Peserta Didik Sekolah Menengah Atas. Sport Science and Health, 2(1), 32-38. Retrieved from http://journal2.um.ac.id/index.php/jik/article/view/11129/5120

Aziz, M.T., 2013. Survei Keterampilan Bermain Futsal Peserta Ekstrakurikuler Futsal di SMK Muhamadiyah 1 Patuk Gunung Kidul. Skripsi. Jurusan Pendidikan Olahraga, UNY.

Barbero-Alvarez, J. C., Subiela, J. V., Granda-Vera, J., Castagna, C., Gómez, M., \& Del Coso, J. (2015). Aerobic fitness and performance in elite female futsal players. Biology of Sport. https://doi.org/10.5604/20831862.1189200

Cooney, G., Dwan, K., \& Mead, G. (2014). Exercise for depression. JAMA - Journal of the American Medical Association. https://doi.org/10.1001/jama.2014.4930

Fathoni, A. F. (2018). The Role of Blended Learning on Cognitive Step in Education of Sport Teaching by Adjusting the Learning Style of the Students. https://doi.org/10.2991/isphe-18.2018.49

Fathoni, \& Fajar, A. (2017). Pengembangan Rubrik Penilaian Keterampilan Mata Pelajaran PJOK Materi Bola Besar dan Kecil Kelas VII Semester Genap. DISERTASI Dan TESIS Program Pascasarjana UM.

Garber, C. E., Blissmer, B., Deschenes, M. R., Franklin, B. A., Lamonte, M. J., Lee, I. M., ... Swain, D. P. (2011). Quantity and quality of exercise for developing and maintaining cardiorespiratory, musculoskeletal, and neuromotor fitness in apparently healthy adults: Guidance for prescribing exercise. Medicine and Science in Sports and Exercise. https://doi.org/10.1249/MSS.0b013e318213fefb

Instituto Brasileiro de Pesquisa e Ensino em Fisiologia do Exercício, R., Cardoso, M. F. da S., Cicero Moraes, J., Cunha, G. dos S., Eloi Gomes Voser, P., \& Morais, M. L. (2017). Revista brasileira de futsal e futebol. RBFF - Revista Brasileira de Futsal e Futebol, ISSN-e 1984-4956, Vol. 9, №. 34, 2017, Págs. 258-264.

Kuncoro, R. adi C. (2016). Tingkat Keterampilan Dasar Bermain Futsal Peserta Ekstrakurikuler Futsal Di Sekolah Menengah Atas Negeri 3 Sragen. Journal of Chemical Information and Modeling.

Kurniadi, D. A. E., Wahyudi, U., \& Heynoek, F. P. (2019). Hubungan Kebiasaan Merokok terhadap Tingkat Kesegaran Jasmani Peserta Ekstrakurikuler Futsal Putra. Sport Science and Health, 1(2), 126-131. Retrieved from http://journal2.um.ac.id/index.php/jfik/article/view/10631/4793

Litardiansyah, B. A., \& Hariyanto, E. (2020). Survei Kondisi Fisik Peserta Ekstrakurikuler Futsal Putra dan Putri Sekolah Menengah Atas. Sport Science and Health, 2(6), 331-339. Retrieved from http://journal2.um.ac.id/index.php/jfik/article/view/14090/5925

Maruhashi, T., Kihara, Y., \& Higashi, Y. (2017). Exercise. In Therapeutic Angiogenesis. https://doi.org/10.1007/978-981-10-2744-4_15

Moore, R., Bullough, S., Goldsmith, S., \& Edmondson, L. (2014). A Systematic Review of Futsal Literature. American Journal of Sports Science and Medicine. https://doi.org/10.12691/ajssm-2-3-8

Naser, N., Ali, A., \& Macadam, P. (2017). Physical and physiological demands of futsal. Journal of Exercise Science and Fitness. https://doi.org/10.1016/j.jesf.2017.09.001

Ninzar, K., 2018. Tingkat Daya Tahan Aerobik ( $\mathrm{VO}_{2} \mathrm{max}$ ) Pada Anggota Tim Futsal Siba Semarang. e-Jurnal Mitra Pendidikan 2, 738-749.

Prasojo, D.A., Junaidi, S., Hidayah, T., 2015.Profil Kebugaran Jasmani Pemain Futsal SMK Bagimu Negeriku Semarang Tahun 2014. Journal of Sport Sciences and Fitness

Rohmatunisha, S., Wahyudi, U., \& Yudasmara, D. S. (2020). Survei Minat Siswa dalam Mengikuti Kegiatan Ekstrakurikuler Bolabasket pada Peserta Sekolah Menengah Pertama. Sport Science and Health, 2(2), 119-129. Retrieved from http://journal2.um.ac.id/index.php/jik/article/view/11266/5286 
Sadewa, A. B. D., \& Nurrochmah, S. (2020). Survei Kondisi Fisik Peserta Kegiatan Ekstrakurikuler Bolabasket Sekolah Menengah Pertama. Sport Science and Health, 2(6), 323-330. Retrieved from http://journal2.um.ac.id/index.php/jfik/article/view/12012/5924

Stanton, R., \& Reaburn, P. (2014). Exercise and the treatment of depression: A review of the exercise program variables. Journal of Science and Medicine in Sport. https://doi.org/10.1016/j.jsams.2013.03.010

Sulistiantoro, D., 2016. Tingkat Keterrampilan Teknik Dasar Bermain Futsal Siswa Pada Tim Futsal Putra Dan Putri di SMAN 1 Sewon Yang Mengikuti PAFTahun 2015. Pendidikan Jasmani Kesehatan dan Rekreasi 